\title{
Penerapan model PBL materi aplikasi gelombang elektromagnetik hasil analisis kontaminan daging menggunakan metode spektroskopi
}

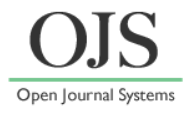

\author{
Ria Aprilia ${ }^{1 *}$, Nirwana ${ }^{2}$, M. Lutfi Firdaus ${ }^{1}$ \\ ${ }^{1}$ Pascasarjana Pendidikan IPA FKIP Universitas Bengkulu, Bengkulu \\ ${ }^{2}$ Pendidikan Fisika FKIP Universitas Bengkulu, Bengkulu \\ *Email : apriliaria815@gmail.com
}

DOI: https://doi.org/10.33369/pendipa.3.3.114-119

\begin{abstract}
[Implementation PBL model in electromagnetic wave material from analysis result of meat contaminant with spectroscopy method]. The aims at this study was to explain differences in learning outcomes between students who study with Problem Based Learning Learning Model (PBL) with students who study conventionally on Electromagnetic Waves material. This method of educational research used quasi experimental research methods. The design of this research is pretest-posttest control group design. Population in this research is all class X SMA Negeri 9 Lubuklinggau, which consists of 4 classes and selected as sample is class $X_{.1}$ as experiment class and $X_{._{2}}$ as control class. Technique of collecting data used is test. The hypothesis of this study is that there are differences in learning outcomes between students learning to use Problem Based Learning (PBL) learning model with students who study conventionally in Physics learning at SMA Negeri 9 Lubuklinggau. Differences can be seen from the results of the mean values of the control and experimental classes, the control class has an average grade value of 80.09 and the experimental class has an average value of 87.25. Based on result of analysis obtained from t test, that is tcount bigger than ttable with value 4,64>1,68 then $H_{0}$ refused and $H_{a}$ accepted. Thus the hypothesis proposed in this study accepted the truth.
\end{abstract}

Keywords: Learning Outcomes; Problem Based Learning (PBL); Electromagnetic Waves; Spectroscopy.

(Received February 20, 2018; Accepted July 15, 2019; Published October 8, 2019)

\begin{abstract}
ABSTRAK
Penelitian ini bertujuan untuk menjelaskan perbedaan hasil belajar antara siswa yang belajar dengan Model Pembelajaran Problem Based Learning (PBL) dengan siswa yang belajar secara konvensional pada materi Gelombang Elektromagnetik. Metode penelitian pendidikan ini menggunakan metode penelitian eksperimen semu. Desain penelitian ini adalah pretest-posttest control group design. Populasi dalam penelitian ini adalah seluruh kelas X SMA Negeri 9 Lubuklinggau, yang terdiri dari 4 kelas dan yang terpilih sebagai sampel adalah kelas $\mathrm{X}_{._{1}}$ sebagai kelas eksperimen dan $\mathrm{X}_{._{2}}$ sebagai kelas kontrol. Teknik pengumpulan data yang digunakan adalah tes. Hipotesis penelitian ini adalah ada perbedaan hasil belajar antara siswa yang belajar menggunakan model pembelajaran Problem Based Learning (PBL) dengan siswa yang belajar secara konvensional pada pembelajaran Fisika di SMA Negeri 9 Lubuklinggau. Perbedaan dapat dilihat dari hasil nilai rata-rata kelas kontrol dan eksperiman, kelas kontrol memiliki nilai rata-rata kelas 80,09 dan kelas eksperimen memiliki nilai rata-rata 87,25. Berdasarkan hasil analisis yang diperoleh dari uji $t$, yaitu $t_{\text {hitung }}$ lebih besar daripada $t_{\text {tabel }}$ dengan nilai 4,64 $>$ 1,68 maka $\mathrm{H}_{0}$ ditolak dan $\mathrm{H}_{\mathrm{a}}$ diterima. Dengan demikian hipotesis yang diajukan dalam penelitian ini diterima kebenarannya.
\end{abstract}

Kata kunci: Hasil Belajar; Problem Based Learning (PBL); Gelombang Elektromagnetik; Spektroskopi. 


\section{PENDAHULUAN}

Pendidikan di sekolah pada umumnya merupakan proses kegiatan belajar dan mengajar berupa interaksi antara siswa dan guru dalam kegiatan pembelajaran, namun kenyataannya masih banyak pembelajaran yang hanya berpusat pada guru. Kegiatan pembelajaran berpusat pada guru artinya pembelajaran tersebut masih menggunakan metode tradisional (Gok, 2008). Kegiatan pembelajaran seperti itu akan membentuk komunikasi satu arah yaitu dari guru kepada siswa, hal ini yang menyebabkan siswa sulit untuk mengembangkan daya nalarnya dalam pemecahan permasalahan dan mengaplikasikan konsep-konsep yang telah dipelajari dalam kehidupan sehari-hari sehingga kemampuan pengetahuan siswa kurang dapat berkembang secara optimal.

Kurang optimalnya kegiatan belajar diatas karena pemilihan dan penggunaan model pembelajaran yang tidak tepat waktu, sasaran dan materi. Pemilihan model pembelajaran dapat memacu peserta didik untuk lebih aktif dalam belajar. Salah satu model pembelajaran yang dapat menantang kemampuan dan keaktifan siswa yang tidak membuat siswa bosan serta mudah untuk memahami pelajaran Fisika adalah model pembelajaran Problem-Based Learning (PBL). Problem Based Learning atau disingkat PBL merupakan salah satu contoh model pembelajaran yang inovatif yang dapat memberikan pembelajaran yang aktif kepada siswa (Susilawati, 2018). Dalam kelas PBL dapat terjadi komunikasi secara efektif dan siswa mampu berkolaborasi dengan siswa lain dalam melakukan percobaan (Cennamo, dkk, 2011). Penelitian Bilgin (2009) menunjukan siswa yang mendapat perlakuan dengan model PBL memiliki kenerja ilmiah dan hasil belajar yang lebih baik dari pada siswa pada kelompok konvensional.

Model Problem Based Learning (PBL) adalah salah satu contoh strategi pembelajaran konstruktivistik yang menimbulkan situasi kontekstual yang signifikan di dunia nyata, dan menyediakan sumber daya bimbingan dan instruksi untuk belajar, karena mengembangkan pengetahuan konten dan keterampilan memecahkan masalah (Folashade, 2009).
Menurut Dimyati (2009) Hasil belajar adalah ukuran atau tingkat keberhasilan yang dapat dicapai oleh seorang siswa berdasarkan pengalaman yang diperoleh setelah dilakukan evaluasi berupa tes dan biasanya diwujudkan dengan nilai atau angka-angka tertentu serta menyebabkan terjadinya perubahan kognitif. Model PBL juga merupakan tahapan belajar yang meningkatkan partisipasi serta berkontribusi dalam pencapaian hasil belajar yang diinginkan (Fong Ma, dkk, 2008). Model PBL ini sangat mendukung pembelajaran fisika terutama pada materi gelombang elektromagnetik.

Gelombang elektromagnetik merupakan gelombang yang tidak memerlukan medium untuk merambat (Giancoli, 2007). Gelombang elektromagnetik telah bayak diaplikasikan dalam peralatan elektronik. Salah satu aplikasi gelombang elektromagnetik adalah alat spektrometer yang menggunakan metode spektroskopi. Spektrometer adalah alat untuk mengukur absorbansi suatu sampel sebagai fungsi panjang gelombang, tiap media akan menyerap cahaya pada panjang gelombang tertentu tergantung pada senyawa atau warna terbentuk (Cairns, 2009). Alat ini dapat digunakan untuk menganalisis kontaminan berbagai olahan daging, seperti pratikum yang telah dilakukan pada Laborotorium FKIP Kimia Universitas Bengkulu. Spektrometer digunakan untuk mengukur nilai absorbansi sampel daging dan sampel olahan daging. Tiap sampel akan menyerap cahaya pada panjang tertentu tergantung pada pemutaran skala yang ada di alat spektrometer.

Sebagian hasil penelitian menggunakan alat spektrometer akan dijadikan sebagai bahan Lembar Kerja Siswa (LKS) di kelas. Penelitian di dalam kelas akan lebih efektif apabila dilakukan eksperimen terstruktur dengan menggunakan Lembar Kerja Siswa (LKS). Pada proses pembelajaran fisika, lembar kejra siswa (LKS) dapat digunakan sebagai alat bantu (Putra, 2018). Sehingga penelitian akan lebih aktif dan efektif dalam kegiatan belajar mengajar saat berada di kelas.

Menurut Darmodjo (1992), LKS adalah sarana pembelajaran yang digunakan guru dalam meningkatkan keterlibatan atau aktivitas siswa 
dalam proses belajar-mengajar. Pendapat lainnya dikemukakan oleh Surachman (1998) yang menyatakan LKS sebagai jenis hand-out digunakan untuk membantu siswa belajar secara terarah (guided discovery activities).

Lembar Kerja Siswa (LKS) juga dapat diartikan sebagai salah satu instrumen belajar yang telah banyak dianggap lebih efektif karena didalam LKS tersusun atas kegiatan praktikum terstruktur dengan panduan (langkah-langkah) kegiatan, soal dan teori yang akan dijelaskan secara terperinci tanpa harus banyak menyimpangkan materi. Lembar Kerja Siswa (LKS) juga dapat mempermudah dan meminimalisir waktu belajar siswa untuk pencapaian tujuan belajar serta meningkatkan hasil belajar siswa. Hasil belajar siswa dapat meningkat karena siswa akan lebih memahami konsep materi yang ada pada LKS.

Dari uraian di atas, maka peneliti tertarik untuk melakukan penelitian pendidikan dengan penerapan model PBL materi aplikasi gelombang elektromagnetik hasil analisis kontaminan daging menggunakan Spektroskopi. Penelitian ini bertujuan untuk menjelaskan perbedaan hasil belajar siswa dengan model Problem Based Learning (PBL) menggunakan Lembar Kerja Siswa (LKS) dan siswa yang belajar secara konvensional.

\section{METODE PENELITIAN}

Penelitian ini dilaksanakan di SMA Negeri 9 Lubuklinggau dengan menggunakan metode penelitian eksperimen semu dan desain pretestposttest control group design. Populasi penelitian ini seluruh kelas $X$ di SMA Negeri 9 Lubuklinggau yang terdiri dari 4 kelas sebagai polulasi. Pemilihan sampel dipilih secara acak (random sampling), sampel yang telah terpilih yaitu kelas kontrol $\left(\mathrm{X}_{.2}\right)$ dan kelas eksperimen $\left(\mathrm{X}_{._{1}}\right)$. Pembelajaran di kelas eksperimen menggunakan model PBL, sedangkan kelas kontrol menggunakan pembelajaran konvensional dengen metode ceramah.

Tehnik pengumpulan data penelitian ini menggunakan tes berbentuk soal essay. Soal yang diberikan merupakan soal Fisika pada materi gelombang elektromagnetik. Sebelum dilakukan penelitian siswa diberikan soal tes untuk mengetahui kemampuan awal antara siswa di kelas kontrol maupun eksperimen. Hasil pretest dianalisis menggunakan tehnik analisis data dengan cara menentukan nilai rata-rata dan simpangan baku, uji normalitas, uji homogenitas dan uji t. Setelah hasil pre-test memenuhi syarat analisis, peneliti baru dapat dilanjutkan pemberian perlakukan kepada kelas eksperimen pembelajaran dengan model Problem Based Learning (PBL). Sedangkan kelas kontrol diberi pembelajaran secara konvensional dengan metode ceramah.

Setelah diberikan perlakukan pada masingmasing kelas, lalu kelas kontrol maupun eksperimen diberikan soal post-test yang bertujuan untuk mengetahui kemampuan akhir siswa. Hasil post-test digunakan untuk mengetahui perbedaan hasil belajar siswa.

\section{HASIL DAN PEMBAHASAN}

\section{Kemampuan Awal Siswa (pre-test)}

Pelaksanaan tes kemampuan awal dilaksanakan untuk mengetahui kemampuan awal siswa terhadap materi gelombang elektromagnetik sebelum siswa mendapatkan pembelajaran dari peneliti. Soal pre-test yang digunakan berbentuk soal essay yang terdiri dari 7 soal. Adapun rekapitulasi perhitungan hasil pre-test kelas eksperimen dan kontrol dapat dilihat pada Tabel 1.

Tabel 1. Rekapitulasi hasil Pre-Test kelas eksperimen dan kelas kontrol

\begin{tabular}{clcc}
\hline No & \multicolumn{1}{c}{ Uraian } & $\begin{array}{c}\text { Kelas } \\
\text { Eksperimen }\end{array}$ & $\begin{array}{c}\text { Kelas } \\
\text { Kontrol }\end{array}$ \\
\hline 1 & Nilai rata-rata & 13,25 & 12,95 \\
& kelas & 1 & 3 \\
2 & Nilai terkecil & 24 & 26 \\
3 & Nilai terbesar & 23 & 23 \\
4 & Rantang nilai & 4,69 & 5,48 \\
5 & Simpangan Baku & & \\
\hline
\end{tabular}

Berdasarkan Tabel 1, dapat dilihat bahwa nilai rata-rata kelas dan simpangan baku pre-test dari kelas eksperimen adalah 13,25 dan 12,95. Sedangkan nilai rata-rata dan simpangan baku pre-test dari kelas eksperimen dan kelas kontrol adalah 4,69 dan 5,48. Jadi, selisih rata-rata dan 
simpangan antara kelas eksperimen dan kelas kontrol adalah 0,3 dan 0,79. Artinya tidak ada siswa yang mendapatkan nilai ketuntasan minimum $\geq 77$.

\section{Kemampuan Akhir Siswa (post-test)}

Kemampuan akhir siswa (post-test) ini dilakukan pada pertemuan keempat. Post-test ini dilaksanakan untuk megetahui hasil belajar akhir siswa pada materi gelombang elektromagnetik setelah diberi pembelajaran oleh guru (peneliti) baik kelas kontrol maupun eksperimen.

Soal post-test yang diberikan sama dengan soal pre-test yang berjumlah 7 soal tanpa ada perbedaaan dan perubahan soal, rekapitulasi perhitungan hasil post-test kelas eksperimen dan kelas kontrol dapat dilihat pada Tabel 2.

Tabel 2. Rekapitulasi Hasil Post-Test Kelas Eksperimen dan Kelas Kontrol

\begin{tabular}{clcc}
\hline No & \multicolumn{1}{c}{ Uraian } & $\begin{array}{c}\text { Kelas } \\
\text { Eksperimen }\end{array}$ & $\begin{array}{c}\text { Kelas } \\
\text { Kontrol }\end{array}$ \\
\hline 1 & Nilai rata-rata & 87,25 & 80,09 \\
& kelas & 76 & 65 \\
2 & Nilai terkecil & 100 & 98 \\
3 & Nilai terbesar & 24 & 33 \\
4 & Rantang nilai & 6,13 & 6,89 \\
5 & Simpangan Baku & & \\
\hline
\end{tabular}

Berdasarkan Tabel 2, rekapitulasi hasil post-test kelas eksperimen dan kelas kontrol dapat dilihat perbedaan hasil belajarnya. Dari hasil tabel di atas terdapat peningkatan dari hasil belajar setelah diberikan pembelajaran. Nilai rata-rata pre-test pada kelas ekperimen adalah 13,25 sedangkan nilai rata-rata post-test adalah 87,25 . Hal ini berarti terjadi selisih nilai rata-rata pada kelas ekperimen sebesar 74. Sedangkan nilai rata-rata pre-test pada kelas kontrol adalah 12,95 sedangkat nilai rata-rata post-test kelas kontrol adalah 80,09. Hal ini berarti terjadi selisih nilai rata-rata pada kelas kontrol sebesar 67,14. Peningkatan pada kelas ekperimen lebih besar dibandingkan pada kelas kontrol. Sedangkan selisih rata-rata dan simpangan baku post-test dari kelas ekperimen dan kelas kontrol adalah sebesar 1,14 dan 1,41.

Dari kegiatan post-test pada kelas ekperimen siswa yang mendapat nilai $\geq 77$ sebanyak 19 siswa sedangkan siswa yang mendapat nilai $<77$ sebanyak 1 siswa. Dari kegiatan post-test pada kelas kontrol siswa yang mendapat nilai $\geq 77$ sebanyak 15 siswa sedangkan siswa yang mendapat nilai $<77$ sebanyak 7 siswa.

Nilai rata - rata kelas kegiatan pretest dan post-test kontrol maupun kelas eksperimen pada kegiatan pre-test dan post-test dapat digambarkan pada Gambar 1.

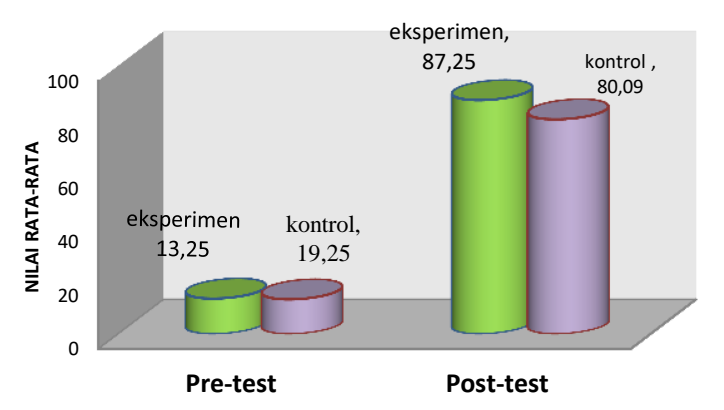

Gambar 1. Perbedaan nilai rata-rata antara pretest dan post-test

Dari Gambar 1 dapat dihitung selisih hasil pre-test dan post-test pada kelas eksperimen mendapatkan nilai 74 , sedangkan pada kelas kontrol mendapatkan nilai 67,14 .

\section{Uji Normalitas}

Uji normalitas bertujuan untuk melihat apakah data hasil siswa berdistribusi normal atau tidak. Berdasarkan ketentuan perhitungan statistik mengenai uji normalitas data dengan taraf kepercayaan $\alpha=0,05$, jika $x_{\text {hitung }}^{2}<$ $x^{2}$ tabel maka masing-masing data berdistribusi normal. Hasil perhitungan uji normalitas dapat dilihat pada Tabel 3.

Tabel 3. Rekapitulasi hasil uji normalitas skor pre-test dan post-test

\begin{tabular}{|c|c|c|c|c|}
\hline Kelas & $x_{h i t u n g}^{2}$ & dk & $x_{t a b e l}^{2}$ & $\begin{array}{l}\text { Kesim } \\
\text { pulan }\end{array}$ \\
\hline $\begin{array}{l}\text { Eksperimen } \\
\text { 1. Pre-test } \\
\text { 2. Post-test }\end{array}$ & $\begin{array}{l}1,977 \\
0,735\end{array}$ & 4 & 9,488 & Normal \\
\hline $\begin{array}{l}\text { Kontrol } \\
\text { 1. Pre-test } \\
\text { 2. Post-test }\end{array}$ & $\begin{array}{l}1,056 \\
0,437\end{array}$ & 4 & 9,488 & Normal \\
\hline
\end{tabular}


Dari Tabel 3 menunjukkan rekapitulasi hasil uji normalitas skor pre-test dan post-test

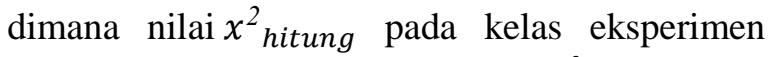
data tes awal (pre-test) lebih kecil $x^{2}{ }_{\text {tabel }}(1,977$ $<9,488) . \quad x^{2}$ hitung data tes akhir (post-test) lebih kecil $x_{\text {tabel }}^{2}(0,735<9,488)$. Dan nilai $x^{2}{ }_{\text {nitung }}$ pada kelas kontrol data tes awal (pre-test) lebih kecil $x^{2}$ tabel $(1,056<9,488)$. $x^{2}$ hitung data tes akhir (post-test) lebih kecil $x^{2}$ tabel $(0,437<9,488)$.

Ketentuan pengujian normalitas yang digunakan untuk uji kecocokan $x^{2}$ (chi-kuadrat) dapat disimpulkan bahwa data pre-test dan posttest berdistribusi normal baik kelas ekperimen maupun kelas kontrol pada taraf kepercayaan $\alpha=$ 0,05 dan derajat kebebasan $(\mathrm{dk})=4$, sehingga dapat dilanjutkan dengan statistik parametris.

\section{Uji Homogenitas}

Uji homogenitas ini bertujuan untuk melihat hasil pre-test dan post-test dari kelas ekperimen dan kelas kontrol apakah data keduanya mempunyai varians yang homogen atau tidak. Uji homogenitas dianalisis setelah perhitungan uji normalitas, hasil penelitian yang telah dilaksanakan uji normalitas berdistribusi normal. Sehingga dapat dilanjutkan dengan uji homogenitas mengunakan persamaan uji F. Hasil uji homogenitas varians tes awal (pre-test) dan tes akhir (post-test) pada taraf kepercayaan $\alpha=$ 0,05 dapat dilihat pada Tabel 4 .

Tabel 4. Hasil Uji Homogenitas Skor Pre-test dan Post-test

\begin{tabular}{ccccc}
\hline $\begin{array}{c}\text { Komp } \\
\text { onen }\end{array}$ & $\mathbf{F}_{\text {hitung }}$ & Dk & $\mathbf{F}_{\text {tabel }}$ & Kesimpulan \\
\hline $\begin{array}{c}\text { Pre- } \\
\text { test }\end{array}$ & 1,43 & $20 ; 21$ & 1,78 & Homogen \\
$\begin{array}{c}\text { Post- } \\
\text { test }\end{array}$ & 1,26 & $20 ; 21$ & 1,78 & Homogen \\
\hline
\end{tabular}

Pada Tabel 4 menunjukkan bahwa nilai $\mathrm{F}_{\text {hitung }}<\mathrm{F}_{\text {tabel }}$ dari hasil pre-test maupun post-test dengan taraf kepercayaan $\alpha=0,05$, jadi varian kedua kelompok yang dibandingkan pada tes awal (pre-test) dan tes akhir (post-test) adalah homogen.

\section{Uji Kesamaan dua rata-rata}

Uji kesamaan dua rata-rata digunakan untuk membuktikan hipotesis pada penelitian. Hipotesis yang diajukan dalam penelitian pendidikan ini adalah:

$\mathrm{H}_{0}$ : Tidak ada perbedaan hasil belajar siswa antara siswa yang belajar dengan menggunakan Model Pembelajaran Problem Based Learning (PBL) dibandingkan dengan siswa yang belajar secara konvensional pada materi Gelombang elektromagnetik.

$\mathrm{H}_{\mathrm{a}}$ : Ada perbedaan hasil belajar siswa antara siswa yang belajar dengan menggunakan Model Pembelajaran Problem Based Learning (PBL) dibandingkan dengan siswa yang belajar secara konvensional pada materi Gelombang elektromagnetik.

Sebelum melakukan uji kesamaan dua rata-rata peneliti telah melakukan uji normalitas serta uji homogenitas varians dari hasil tes awal dan tes akhir pada kelas eksperimen maupun kelas kontrol.

Hasil uji normalitas dari pre-test dan posttest dinyatakan berdistribusi normal dan hasil uji homegenitas varians dinyatakan homogen. Dengan demikian uji kesamaan dua rata-rata antara kelas eksperimen dan kelas kontrol untuk tes awal (pre-test) dan tes akhir (post-test) menggunakan uji-t data disajikan pada Tabel 5.

Tabel 5. Uji Kesamaan Dua Rata-rata tes awal dan tes akhir

\begin{tabular}{ccccc}
\hline Kegiatan & $\mathbf{t}_{\text {hitung }}$ & $\mathbf{d k}$ & $\mathbf{t}_{\text {tabel }}$ & Kesimpulan \\
\hline Pre-test & 0,70 & 40 & 2,10 & $\begin{array}{c}\mathrm{t}_{\text {hitung }}<\mathrm{t}_{\text {tabel }} \\
\mathrm{H}_{\mathrm{o}} \text { diterima }\end{array}$ \\
Post-test & 4,64 & 40 & 2,10 & $\begin{array}{c}\mathrm{t}_{\text {hitung }}>\mathrm{t}_{\text {tabel }} \\
\mathrm{H}_{\mathrm{o}} \text { ditolak }\end{array}$ \\
\hline
\end{tabular}

Dari Tabel 5 menunjukkan hasil analisis uji-t tes awal siswa pada kelas eksperimen dan kelas kontrol memiliki kemampuan awal dengan taraf signifikan $\alpha=0,05$ karena $\mathrm{t}_{\text {hitung }}<\mathrm{t}_{\text {tabel }}(0,70$ $<1,68)$, sedangkan uji-t kemampuan tes akhir menunjukkan jika $t_{\text {hitung }}>t_{\text {tabel }}(4,64>1,68)$.

Setelah diberikan pembelajaran yang berbeda pada kedua kelas (sampel) terjadi peningkatan nilai hasil belajar siswa. Kelas 
eksperimen diberikan pembelajaran dengan model Problem Based Learning (PBL), sedangkan kelas kontrol diberikan dengan pembelajaran konvensional. Dari hasil tersebut dapat dinyatakan bahwa ada perbedaan hasil belajar siswa antara siswa yang belajar dengan menggunakan Model Pembelajaran Problem Based Learning (PBL) dibandingkan dengan siswa yang belajar secara konvensional pada materi Gelombang elektromagnetik.

\section{KESIMPULAN}

Berdasarkan hasil penelitian dapat disimpulkan bahwa ada perbedaan hasil belajar antara siswa yang belajar menggunakan model pembelajaran Problem Based Learning (PBL) dengan siswa yang belajar secara konvensional pada pembelajaran Fisika di SMA Negeri 9 Lubuklinggau, hal ini dapat dilihat dari hasil yang diperoleh berdasarkan uji $t$ yaitu $t_{\text {hitung }}$ lebih besar daripada $t_{\text {tabel }}$ dengan nilai $4,64>1,68$ maka $\mathrm{H}_{0}$ ditolak dan $\mathrm{H}_{\mathrm{a}}$ diterima.

\section{UCAPAN TERIMA KASIH}

Penulis mengucapkan terima kasih kepada Kepala sekolah dan seluruh guru serta staf SMA Negeri 9 Lubuklinggau atas diizinkannya penulis untuk melaksanakan kegiatan penelitian ini.

\section{DAFTAR PUSTAKA}

Bilgin, I., Senocak, E., Sozbilir, M. (2009). The effects of problem based learning instruction on university students' performance of conceptual and quantitative problems in gas concepts. Eurasia Journal of Mathematics, Science \& Technology Education, 5(2), 153-164.

Cairns, D. (2009). Essentials of Pharmaceutical Chemistry Second Edition (Intisari Kimia Farmasi Edisi Kedua). Penerjemah: Puspita Rini. Jakarta: Penerbit Buku Kedokteran EGC.

Cennamo, K., Brandt, C., Scott, B., Dougla,. S., McGrath, M., Reimer, Y., Vernon, M. (2011). Managing the Complexity of Design Problems through Studio-based
Learning. The Interdisciplinary Journal of Problem-Based Learning, 5(2), 12-36.

Darmodjo, Hendro, Kaligis, Jenny, R.E. (1992). Pendidikan IPA. Proyek Pembinaan Tenaga Kependidikan Direktorat Jenderal Pendidikan Tinggi Departemen Pendidikan dan Kebudayaan. Jakarta : Depdikbud.

Dimyati, \& Mudjiono. (2009). Belajar dan pembelajaran. Jakarta: Rineka Cipta.

Folashade, A., Akinbobola, A.O. (2009). Constructivist problem based learning technique and the academic achievement of physics students with low ability level in nigerian secondary schools. Eurasia Journal of Physics and Chemis try Education, 1(1), 45-51.

Fong Ma, A.K., Toole, J.O., Kepple, M. (2008). An Investigation of Student Teachers attitudes to the Use of Media Triggered Problem Based Learning. Australasian Journal of Educational Techonology, 24(3), 311-325.

Giancoli, D.C. (2007). Fisika Edisi Kelima Jilid 1. Jakarta : Penerbit Erlangga.

Gok, T., Silay, I. (2008). Effect of Problem Solving Strategy Teaching on the Problem-Solving Atitude of Cooperating Learning group in Physics education. Journal of Theory and Practice in Education, 4(2), 253-266.

Putra, R., Swistoro, E., Farid, M. (2018). Penggunaan potensial air tanah dan hubungannya dengan kualitas air tanah serta implementasi pada pembelajaran fisika. PENDIPA Journal of Science Education, 2(2), 170-777.

Surachman. (1998). Pengembangan Bahan Ajar. Yogyakarta: Jurusan Pendidikan Biologi FPMIPA IKIP Yogyakarta.

Susilawati, Mayub, A., Farid, M. (2018). Menghitung nilai emisivitas warna menggunakan miniatur ruang berbentuk silinder sebagai media pembelajaran fisika. PENDIPA Journal of Science Education, 2(2), 135-141. 